\title{
Aplikasi M-Commerce Berbasis Android Pada Phone Comp Service
}

\author{
Stefanus Yulianto \\ Progam Studi Teknik Informatika \\ STMIK Atma Luhur \\ Jl. Jend. Sudirman Pangkalpinang \\ stefanus.efanli@gmail.com
}

\author{
Benny Wijaya \\ Program Studi Teknik Informatika \\ STMIK Atma Luhur \\ Jl. Jend. Sudirman Pangkalpinang \\ benny.wijaya@atmaluhur.ac.id
}

\begin{abstract}
Abstrak - Perkembangan bisnis di era modern ini memicu persaingan bisnis yang semakin ketat. Sistem penjualan atau marketing pun ditingkatkan guna mempertahankan dan meningkatkan pemasaran produk. Sistem penjualan yang dengan teknologi modern akan menjadi alternatif penjualan yang baik. Dengan memanfaatkan teknologi smartphone, sistem akan dikembangkan dengan menggunakan metode pengembangan dan pemrograman perangkat lunak yang berorientasi objek (OOP). Untuk pengembangannya digunakan aplikasi Eclipse Juno dan Dreamwever. Aplikasi ini berbasis Mobile Application (Android) menggunakan bahasa pemrograman Java dan MySQL sebagai databasenya dan PHP sebagai web servernya. Metode pengembangan aplikasi menggunakan Metode Prototype. Yang nantinya akan menghasilkan sebuah apliksi m-commerce dengan memanfaatkan sistem aplikasi android pada smartphone. Aplikasi ini nantinya akan sangat berguna untuk toko Phone Comp Service. Aplikasi yang dihasilkan ini berupa aplikasi mobile atau m-commerce yang akan dijalankan pada smartphone android. Dengan aplikasi nantinya akan memudahkan konsumen untuk melakukan pemesanan atau transaksi pada toko Phone Comp Service, sehingga akan lebih mudah efesiensi waktu. Aplikasi ini juga akan meningkatkan omset penjualan toko.
\end{abstract}

Kata Kunci-M-Commerce, Smartphone, Aplikasi, Android, Sistem

\section{Pendahuluan}

Phone Comp Service merupakan salah satu counter $\mathrm{hp}$ (handphone) yang bergerak dibidang penjualan handphone dan aksesorisnya serta service handphone. Sistem pemasaran dan penjualan yang digunakan oleh Phone Comp Service saat ini adalah konsumen harus datang langsung ke Phone Comp Service untuk menanyakan atau melihat ketersediian handphone atau aksesoris handphone yang ingin dibeli. Atau hanya datang untuk melakukan konsultasi service ke Phone Comp Service. Tentunya, dengan sistem penjualan tersebut maka akan menyita waktu konsumen untuk memperoleh informasi dengan mudah dan akurat. Melihat banyak tokotoko lain yang bergerak di bidang yang sama telah memanfaatkan fasilitas-fasilitas dari teknologi informasi. Salah satu aspek yang paling mendukung adalah adanya fasilitas M-Commerce. M-Commerce itu sendiri adalah sistem perdagangan elektronik dengan menggunakan perangkat mobile yang dapat membantu konsumen dalam proses penjualan barang. Dengan adanya M-Commerce, diharapkan Phone Comp Service dapat memasarkan barangnya secara mobile online sehingga konsumen bisa melihat dan memesan pada Phone Comp Service tanpa harus mendatangi toko secara langsung. Selain itu diharapkan dengan adanya M-Commerce pada Phone Comp Service ini dapat meningkatkan grafik pendapatan. Mengacu dari permasalahan diatas, maka perlu dibuat suatu sistem yang dapat menyelesaikan permasalahan yang ada saat ini. Pembangunan aplikasi berbasis mobile pada platform android adalah suatu solusi untuk menyelesaikan berbagai permasalahan di atas guna mencapai efektifitas maupun efisiensi Phone Comp Service.

\section{LANDASAN TEORI}

\section{A. Analisa Sistem}

Analisis Sistem adalah penguraian suatu sistem informasi yang sudah utuh kedalam bagian-bagian komponennya dengan tujuan dapat menidentifikasi dan menevaluasi berbagai macam permasalahan maupun hambatan yang terjadi pada sistem sehingga nantinya dapat dilakukan perbaikan atau pengembangan. Pada analisa sistem penulis hanya melakukan 3 tahapan analisis yaitu, analisa sistem berjalan, analisa sistem usulan dan analisa kebutuhan.

\section{B. UML (Unified Modeling Language)}

Menurut Munawar (2005), UML (Unifiels Modelling Language) adalah salah satu alat bantu yang sangat handal di dunia pengembangan sistem yang berorientasi obyek. Hal ini disebabkan karena UML dilengkapi dengan mekanisme yang efektif untuk berbagi (sharing) dan mengkomunikasikan rancangan mereka dengan yang lain sehingga mudah dimengerti. Dalam penyelesaian skripsi ini tidak menggunakan keseluruhan diagram UML yang telah disebutkan diatas tetapi hanya beberapa saja yaitu activity diagram, use case diagram, dan sequence diagram. 


\section{Aplikasi}

Aplikasi dapat dikatakan suatu perangkat lunak yang siap dipakai dengan menjalankan instruksi-instruksi dari user atau pengguna, aplikasi banyak diciptakan guna membantu berbagai keperluan seperti untuk laporan, percetakan dan lainlain. Istilah aplikasi berasal dari bahasa inggris "application" yang berarti penerapan, lamaran ataupun penggunaan, jadi pengertian aplikasi dapat disimpulkan merupakan program siap pakai yang menbantu mencapai tujuan pengguna.

\section{M-Commerce}

M-Commerce atau mobile commerce sering disebut juga dengan m-business atau pervasive computing. M-Commerce merupakan pengembangan dari e-commerce yang menggunakan jaringan wireless atau mobile telecomunication.

\section{E. Android}

Menurut Supardi (2015), Android merupakan sisstem operasi berbasis Linux yang digunakan untuk telepon seluler (mobile), seperti telepon pintar (Smartphone) dan Komputer Tablet (PDA). Android menyediakan platform terbuka bagi para pengembang untuk menciptakan aplikasi mereka sendiri untuk digunakan oleh bermacam peranti bergerak.

\section{F. JSON}

JSON (JavaScript Object Notation) adalah format pertukaran data yang ringan, mudah dibaca dan ditulis oleh manusia, serta mudah diterjemahkan dan dibuat (generate) oleh komputer. Format ini dibuat berdasarkan bagian dari Bahasa Pemprograman JavaScript.

\section{G. $M y S Q L$}

Menurut Setiyo Cahyono (2006), menyatakan, bahwa MySql Adalah multi user database yang menggunakan bahasa structured querylanguage (SQL). MySQL dalam operasi client - server melibatkan server daemon MySQL di sisi server dan berbagai macam program serta library yang berjalan di sisi client. SQL adalah bahasa standar yang digunakan untuk mengakses database server.

\section{Metode Penelitian}

\section{A. Perencanaan}

Penulis dalam tahap ini mengumpulkan data dan informasi tentang sistem penjualan yang diterapkan oleh Phone Comp Service dengan melakukan observasi dan wawancara.

\section{B. Analisis}

Melakukan beberapa tahapan analisis sebagai berikut :
- Analisis sistem berjalan dan menentukan sistem usulan.

- Analisis kebutuhan perangkat keras dan perangkat lunak.

- Analisis sasaran dari aplikasi.

\section{Perancangan}

Adapun tahapan perancangan sebagai berikut :

- Membuat rancangan sebuah aplikasi mobile dimana terdapat form-form yang akan digunakan untuk melengkapi aplikasi yang dirancang.

- Pengembangan sistem yang akan dibangun ini menggunakan metode pengembangan perangkat lunak berorientasi objek dengan aktifitas yang fokus pada pengembangan model dengan menggunakan Unified Model Languange (UML).

\section{Implementasi}

Untuk tahap ini, penulis akan melihat program yang sudah dibuat dan melakukan pengujian terhadap aplikasi.

Ada 2 tahap yang diambil oleh penulis yaitu :

- Instalasi aplikasi M-Commerce dalam bentuk .apk.

- Pengujian menggunakan blackbox testing.

\section{PEMBAhasan}

\section{A. Analisa Sistem Berjalan}

Informasi tentang sistem yang sedang berjalan sangat penting sekali dalam proses perancangan sistem informasi dari sistem tersebut dapat diketahui sejauh mana sistem yang berjalan sekarang dapat memenuhi kebutuhan pengguna. Adapun sistem berjalan yang terjadi di Phone Comp Service sebagai berikut :

- Konsumen memilih produk yang akan dibelinya lalu memberikannya kepada penjaga toko.

- Penjaga toko menerima produk yang telah dipilih

- Penjaga toko memberitahu kepada konsumen berapa total harga dari produk yang dibelinya.

- Konsumen membayar total harga pruduk yang telah disepekati

- Penjaga toko mengarsipkan data penjualan di buku penjualan barang.

- Penjaga toko membuatkan nota pembelian dan diberikan kepada konsumen beserta baang belanjaanya.

\section{B. Analisa Sistem Usulan}

Adapun sistem usulan untuk solusi masalah yang ada adalah dengan merancang aplikasi m-commerce pada Phone Comp Service. Pada sistem usulan ini, aplikasi client akan dibuat online sehingga konsumen dapat melakukan pemesanan barang dengan memanfaatka ponsel pintar android. Sedangkan 
aplikasi admin menggunakan web server, aplikasi android client akan berhubungan atau terkoneksi disini nantinya. Berikut gambar rancangan sistem usulannya.

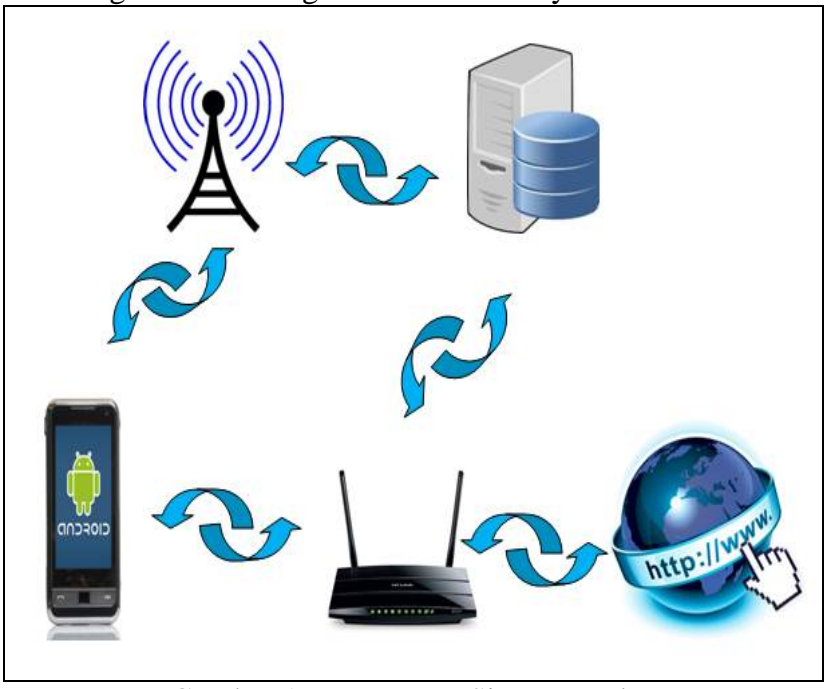

Gambar 1. Rancangan Sistem Usulan

\section{Analisa Kebutuhan}

Tahap analisa kebutuhan bertujuan untuk mendefinisikan kebutuhan dari sistem yang akan dikembangkan. Analisa kebutuhan sistem dibedakan menjadi kebutuhan fungsional dan kebutuhan non fungsional.

1) Analisa Kebutuhan Non Fungsional

Analisa kebutuhan non fungsional adalah analisis yang dibutuhkan untuk menentukan spesifikasi kebutuhan sistem yang meliputi elemen atau komponen yang dibutuhkan untuk sistem yang akan dibangun sampai dengan implementasinya. Dalam pembangunan sistem ini ada 3 (tiga) kebutuhan non fungsional yang digunakan yaitu : kebutuhan pengguna, perangkat keras dan perangkat lunak.

a) Analisa Kebutuhan Pengguna

User Mobile dapat melakukan pencarian produk dengan melihat produk - produk yang ditawarkan dan melakukan pembelian barang.

\section{b) Analisa Kebutuhan Perangkat Keras}

Dalam pembangunan sistem ini dibutuhkan perangkat keras yang sesuai dengan karakteristik rancangan sistem ini. Adapun perangkat keras yang digunakan dalam pembangunan sistem ini adalah sebagai berikut:

- $\quad$ Processor Intel Core i3

Processor ini dipilih karena memiliki kinerja yang bagus dan lebih baik dari produk intel sebelummnya. Lalu kenapa tidak menggunakan core i5 atau diatasnya lagi? Karena core i3 sudah cukup untuk menjalankan atau pengoerasian sistem ini dan juga lebih hemat biaya.
- VGA Card 2GB DDR3

VGA card ini dipilih karena menghasilkan grafis visual yang baik.

- $\quad$ Smartphone Android KitKat 4.4.4

Android dengan sistem operasi KitKat 4.4.4 saya gunakan karena aplikasi ini nantinya hanya kompatibel dengan sistem operasi android KitKat 4.4.4 kebawah. Yang artinya tidak bisa digunakan pada sistem operasi diatas 4.4.4.

\section{c) Analisa Kebutuhan Perangkat Lunak}

Perangkat lunak yang digunakan untuk membangun sistem ini adalah :

- Java Development Kit versi 8

Digunakan untuk mengkompilasi kode program, dan java development kit ini kompatibel dengan spesifikasi laptop yang digunakan

\section{- Java Runtime}

Merupakan platform untuk menjalankan sistem, ini digunakan karena kopatibel dengan eclipse juno.

- Dreamweaver,

Digunakan untuk membangun aplikasi server dengan php script, aplikasi ini dipilih karena mudah digunakan dalam pembangunan aplikasi.

- Eclipse Juno,

Digunakan untuk membangun aplikasi client pada android. Aplikasi ini digunkan karena mudah diinstal dan digunakan dalam pembuatan java script dan juga free.

- Android SDK, untuk pengembangan aplikasi android.

- Android Development Tools, plugin android pada android studio.

- Android Virtual Device, emulator untuk menjalankan sistem android.

Android SDK, Android Development Tools, dan Android Virtual Device menggunakan tools bawaan dari Eclipse Juno yang dapat digunakan dengan mudah.

- Xampp

Perangkat lunak untuk localhost database dan aplikasi. Xampp digunakan karena mudah digunakan dan free.

- $\quad$ Sistem Operasi Windows 7

Sistem Opereasi Windows 7 lebih mudah digunakan, karena sistem operasi ini didesain dengan tampilan yang simple dan juga masyarakat lebih mengenal dan terbiasa menggunakan sistem operasi ini.

\section{- Android OS}

Sistem Operasi Android ini dipilih karena sistem operasi ini bersifat open source, sehingga dapat dikembangkan siapa saja yang nantinya mau mengembangkannya. Selain itu, sistem operasi ini juga sangat banyak digunakan dan ditanamkan di berbagai smartphone saat ini, jadi aplikasi yang telah 
dibuat nantinya dapat digunakan di sistem operasi android.

\section{2) Analisa Kebutuhan Fungsional}

Analisis kebutuhan fungsional bertujuan untuk mengetahui proses informasi yang mengalir melalui perangkat lunak. Analisis dilakukan dengan mendeskripsikan fungsi sistem yang dibangun, mengidentifikasi aktor, membuat use case diagram, activity diagram, dan sequence diagram.

\section{Desain Perancangan Perangkat Lunak}

\section{1) Usecase Diagram}

a) Usecase Admin

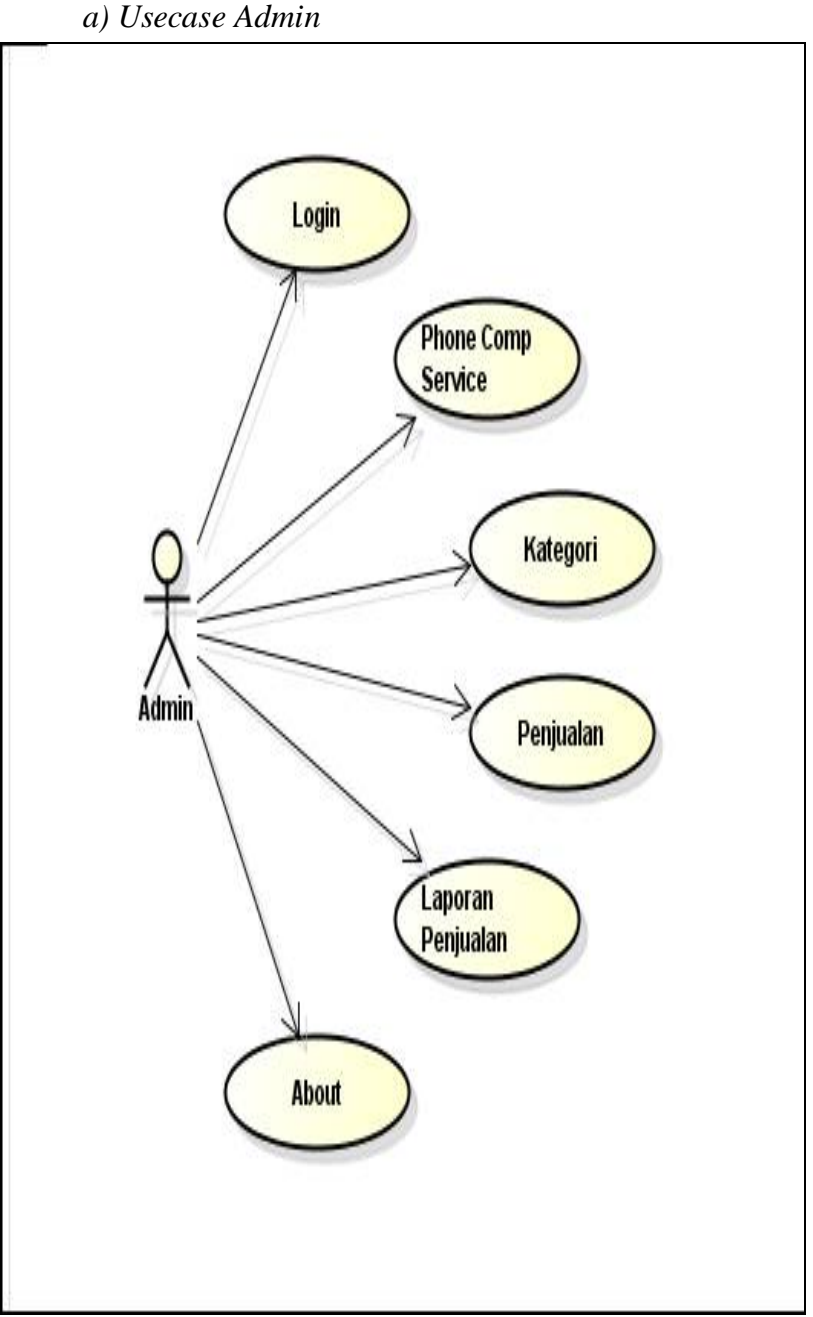

Gambar 2. Usecase Diagram Admin

b) Usecase Diagram User

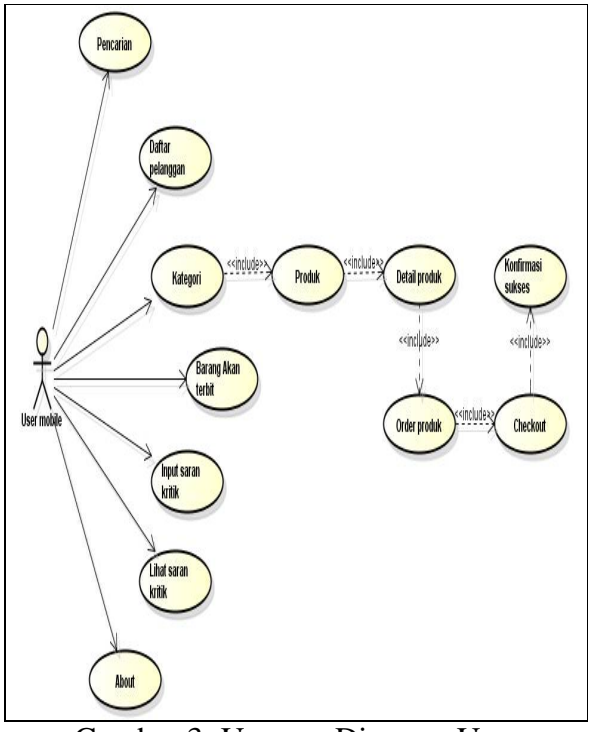

Gambar 3. Usecase Diagram User

\section{2) Activity Diagram}

Activity diagram adalah gambaran grafis dari alur kerja tahapan aktivitas. Adapun activity diagram yang diusulkan dari Aplikasi M-Commerce ini adalah sebagai berikut :

a) Activity Diagram Pemesanan Barang

Pada Activity Diagram pemesanan produk, setelah user membuka aplikasi, user dapat memilih kategori dan produk yang diinginkan. Setelah itu user dapat melakukan pemesanan produk. Dan setelah user selesai melakukan pemesanan barang hingga proses transaksi terakhir, selanjutnya user mendapatkan konfirmasi. Berikut activity diagram pemesanan barang :

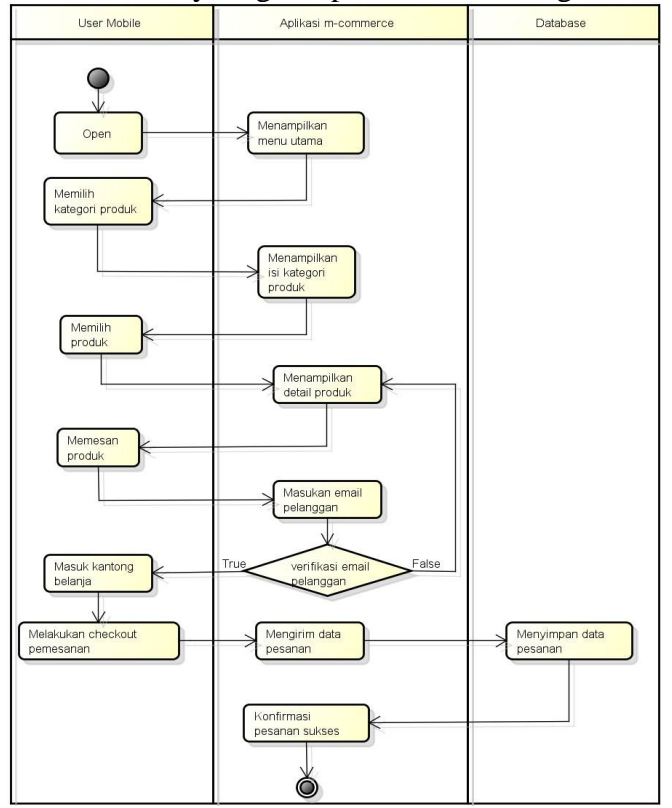

Gambar 4. Activity Diagram Pemesanan Barang 


\section{3) Sequence Diagram}

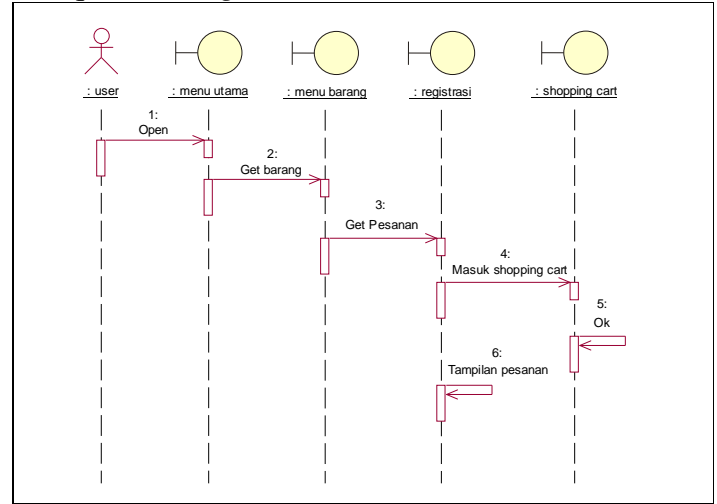

Gambar 5. Sequence Diagram Shoping Cart

\section{E. Rancangan Layar}

Rancangan layar merupakan suatu hal yang penting dalam membuat suatu aplikasi. Tampilan yang dibuat haruslah menarik, tidak membingungkan dan mudah dimengerti. Kemudahan itu sangat diperlukan agar pemakai merasa nyaman dan tidak jenuh saat menjalankan sistem. Berikut rancangan layar usulannya:

\begin{tabular}{|l|}
\hline LOGO \\
\hline CARI \\
\hline Kategori \\
\hline Kategori \\
\hline Kategori \\
\hline Kategori \\
\hline
\end{tabular}

Gambar 6. Rancangan Layar Menu Utama

\section{F. Tampilan Layar}

Berikut desain tampilan antarmuka (interface) pada aplikasi android dilakukan dengan sebuah layout. Adapun tampilan aplikasi M-Commerce yang akan diterapkan di smartphone untuk mudah dimengerti oleh user/pengguna.

1) Tampilan Layar Aplikasi Client

a) Tampilan Layar Menu Utama

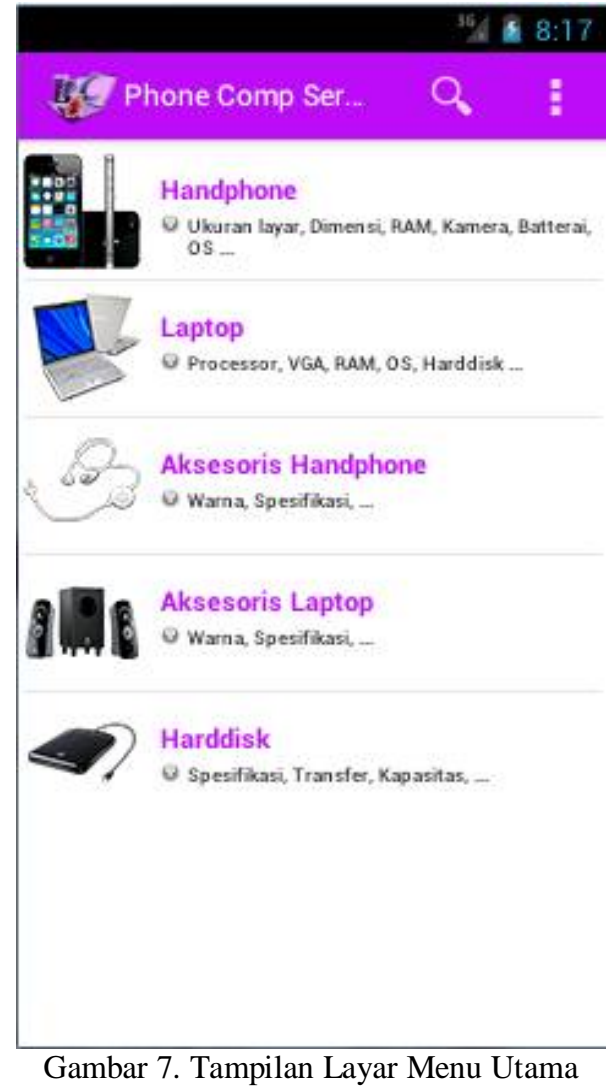

b) Tampilan Layar Daftar Pelanggan

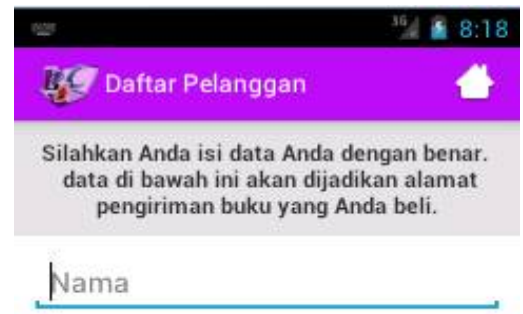

Alamat

Email

Telepon

\section{Proses Batal}

Gambar 8. Tampilan Daftar Pelanggan 
c) Tampilan Layar Daftar Barang

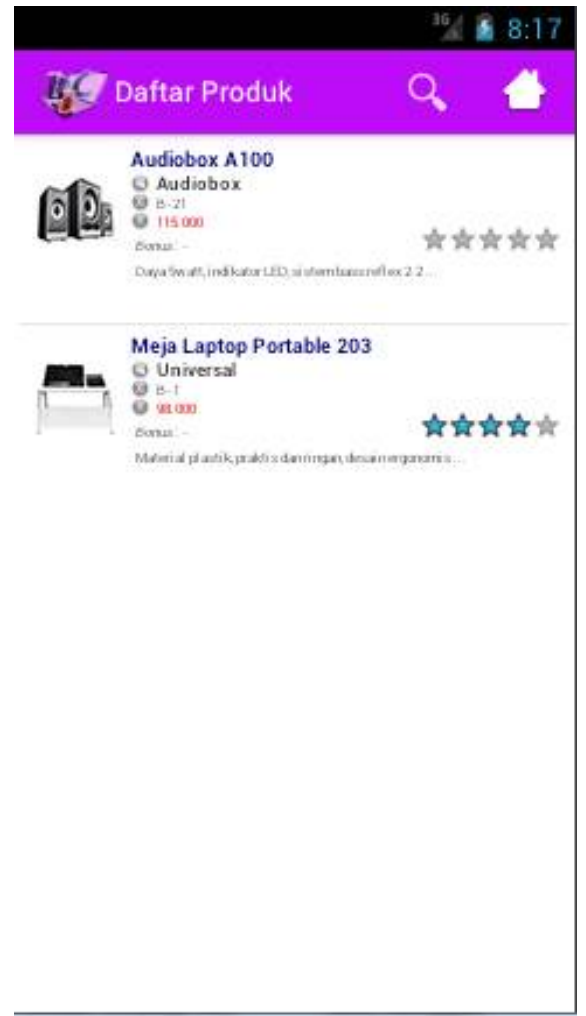

Gambar 9. Tampilan Daftar Barang

d) Tampilan Layar Kantong Belanja

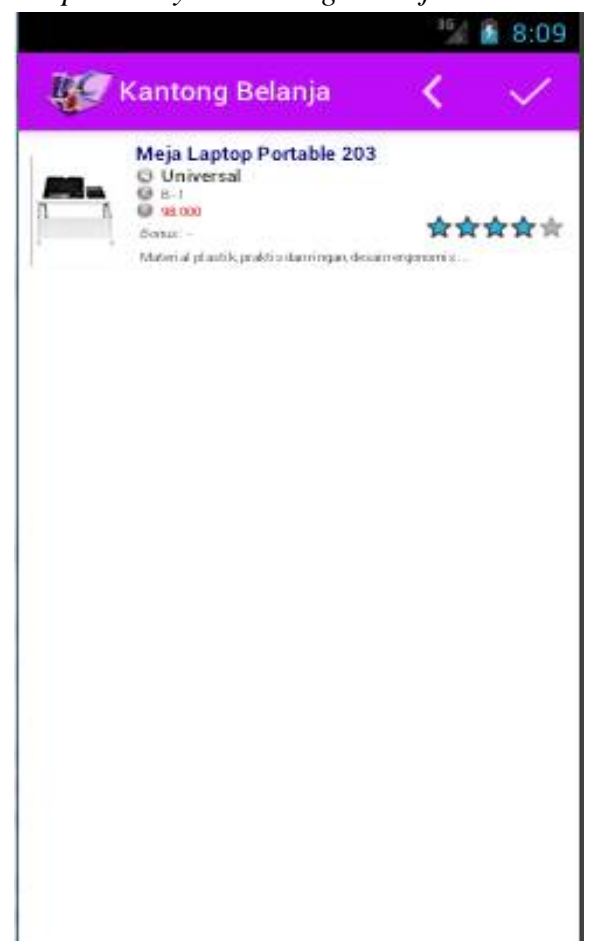

Gambar 10. Tampilan Layar Kantong Belanja e) Tampilan Layar Checkout

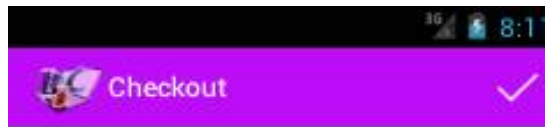

Transaksi Anda telah diproses, informasi tentang transaksi Anda silahkan dilihat pada keterangan di bawah ini :

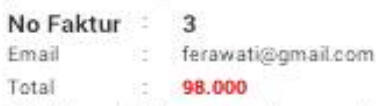

Silahkan lakukan pembayaran ke rekening kami, dan informasikan pembayaran Anda melalui sms dengan format :

(Sudai Transler = Faktur-Enal-Tolal Traisles) Info Rekening Bank :

BCA 1810622845 Chtrstia Canelia

\section{Gambar 11. Tampilan Checkout}

2) Tampilan layar Aplikasi Server

a) Tampilan Menu Login

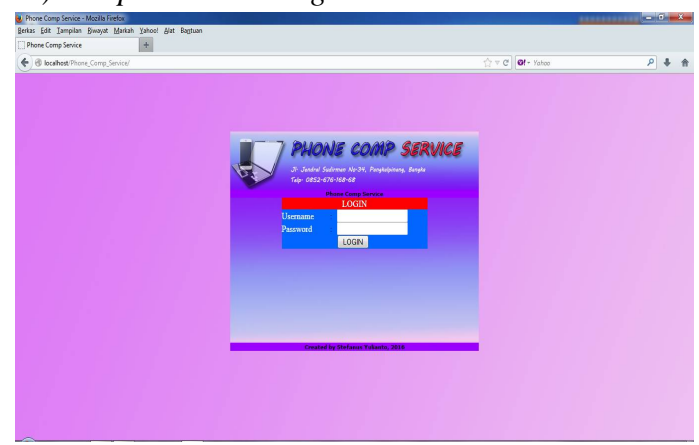

Gambar 12. Tampilan Menu Login

b) Tampilan Layar Menu Utama

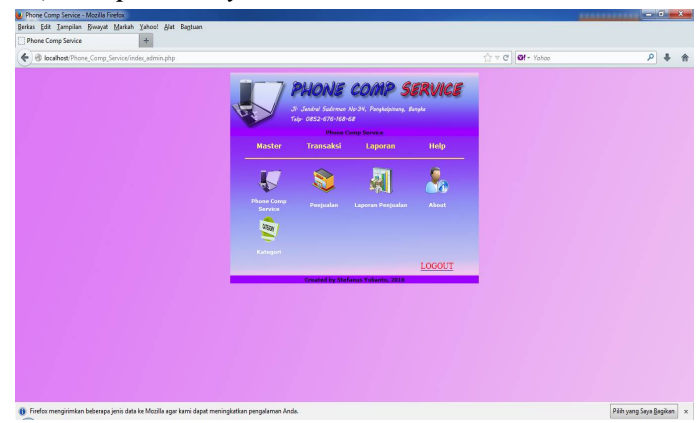

Gambar 13. Tampilan Menu Utama 


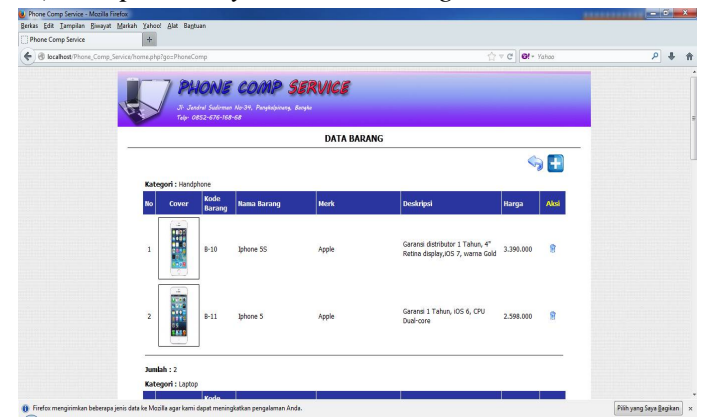

Gambar 14. Tampilan Data Barang

\section{d) Tampilan Layar Tambah Data Barang}

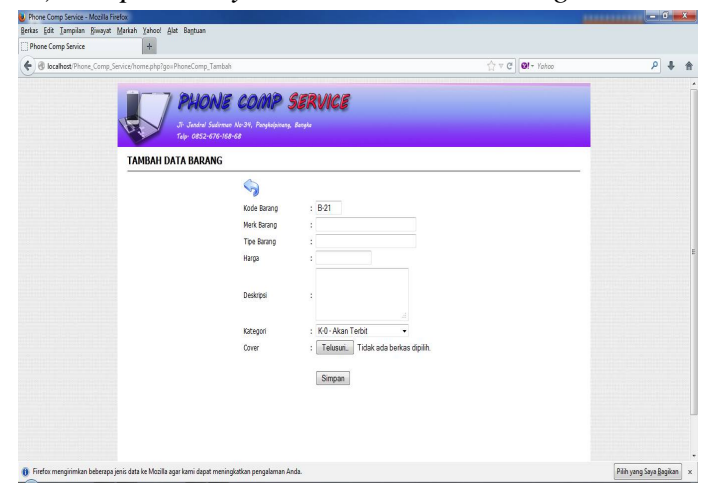

Gambar 15. Tampilan Tambah Data Barang

\section{e) Tampilan Layar Laporan Penjualan}

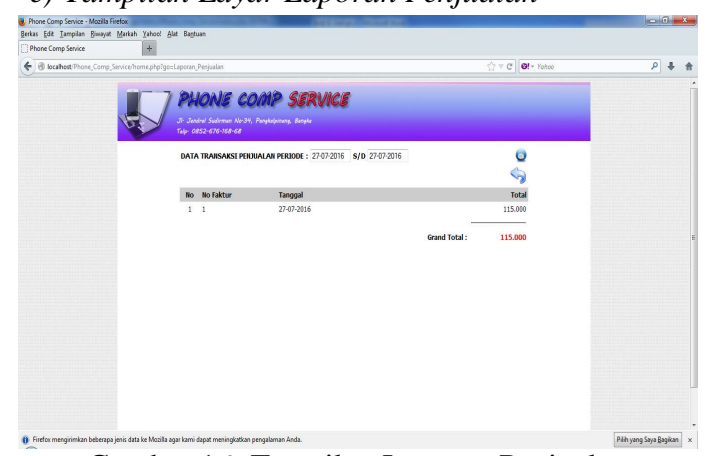

Gambar 16. Tampilan Laporan Penjualan

\section{Penutup}

\section{A. Kesimpulan}

Berdasarkan uraian dan hasil analisa yang telah dilakukan selama pengerjaan Aplikasi Mobile Commerce pada Phone Comp Service berbasis Android ini, maka dapat diambil kesimpulan sebagai berikut :

- Aplikasi m-commerce ini dapat mempermudah konsumen dalam melakukan pemesanan barang via mobile di Phone Comp Service.

- Dengan adanya aplikasi m-commerce konsumen tidak perlu datang langsung ke toko untuk melakukan transaksi, sehingga lebih mudah dan efesiensi waktu.

- Aplikasi m-commerce ini juga dapat menambah omset penjualan Phone Comp Service dan juga dapat memperluas pemasaran toko.

\section{B. Saran}

Adapun saran yang dapat penulis berikan untuk pengembangan dari sistem yang telah di buat antara lain :

- Aplikasi ini dapat dikembangan dengan menambah fitur-fitur baru yang dibutuhkan user guna menyempurnakan aplikasi yang ada.

- Aplikasi ini dapat dikembangan dengan metode pembayaran yang terintegrasi dengan aplikasi dengan sistem paypal.

\section{DAFTAR PUSTAKA}

[1] Cahyono, S. Panduan Praktis Pemrograman Database Menggunakan MySQL dan JAVA. Bandung: Informatika, 2006.

[2] Henderi. Analysis and Design System with Unified Modeling Language (UML) STMIK Raharja: Tangerang, 2007.

[3] I Putu Agus Eka Pratama I Putu Agus Eka, E-Commerce, E-Business, dan Mobile Commerce. Bandung: Informatika Bandung, 2015.

[4] Mulya Yosef. Pemograman Android BlackBox: Jasakom, 2014.

[5] Munawar. Pemodelan Visual dengan UML. Yogyakarta; Graha Ilmu 2005.

[6] Rosa A.S dan M. Shalahuddin. Rekayasa Perangkat Lunak Terstruktur dan Berorientasi Objek. Informatika Bandung 2015.

[7] Simarmata, Janner. Aplikasi Mobile Commerce Menggunakan PHP dan MySQL. Yogyakarta: Andi, 2015.

[8] Supardi, Ir. Yuniar. Semua Bisa Menjadi Programmer Android. Jakarta: PT Elex Media Komputindo, 2014.

[9] Supardi, Y. Belajar Coding Android bagi Pemula. Jakarta, 2015

[10] Simarmata, Aplikasi Mobile Commerce Menggunakan PHP dan MySQL, edisi 1, ANDI, Yogyakarta, 2006. 